the British Chemical Abstracts; and that these specialised abstracts are widely appreciated. In so far as a large number of members of the Society of Public Analysts are members also of one or both of the societies maintaining the Bureau of Chemical Abstracts, no reasonable objection can be raised to this action. None the less, the unprejudiced onlooker may regret the example when overlapping and duplication are still so widely apparent in chemical literature, and when the major scientific societies find the burden of publication a severe tax on their resources. He may still be entitled to conclude that it is idle to deplore such financial limitations or to lament the growing difficulty which besets every scientific worker of keeping abreast of his subject until there is to be found a much greater willingness to make generous sacrifices in the general interest. It is unfortunate that a phrase in the original article, intended merely to indicate the ground covered by the abstracts of the Society of Public Analysts, has been construed to refer to the matter and data of the abstracts in a way which the Society would have been justly entitled to resent. Such criticism of any society is, however, most effectively disarmed by the measure in which the Society publicly as well as privately supports the central institutions for the co-ordination of scientific literature in the particular science it avows.

\section{Export of Antiquities from Egypt}

A REPORT from Cairo points to the possibility of further restrictions on the export of antiquities from Egypt. Under the existing antiquities law, which has been in operation for a little more than a decade, the rights of the State in the allocation of the proceeds of legitimate excavation have been well-indeed some would say too well-protected; but it has proved difficult to check clandestine digging. The finds from these illicit activities frequently, but not invariably, find a final resting place in the Cairo museum, but a considerable number still are smuggled out of the country. According to a dispatch from the Cairo correspondent of The Times in the issue of May 25, violent protest has been raised in the Arab newspapers as a result of reports of the value of papyri, and especially of the new fragments of a Gospel now in the British Museum, which have been sold at high prices to European collections. Inquiries by The Times correspondent have elicited the admission that sales by Cairo dealers to private collectors have been due to the fact that the Cairo Museum has not shown an interest in papyri except when of historical importance. As a consequence of this agitation, however, the Minister of Education, Nequid Bey Hilali, has appointed a committee to inquire into the question of illicit sales of antiquities. Although archæologists may sometimes have felt the burden of the regulations imposed upon legitimate excavation to be unduly irksome, they will have no quarrel with any measure checking that destruction of scientific evidence which is the inevitable accompaniment of clandestine digging and illicit sales.

\section{Control of Architecture}

THобGн a nation may not be judged wholly by its architecture, this at least forms an outward and visible sign of its mentality, and since many buildings outlive a number of generations, it is our duty to posterity to see that the structures we erect are not only fitted for their purposes, but also are outwardly gracious and in harmony with their surroundings. Great developments in building are in progress, municipal, institutional, commercial and most of all domestic owing to the programmes of slum clearance. These developments merit the employment of only qualified architects, to ensure the greatest economy in the expenditure of money and the most suitable results in design which proper training can alone give. The Royal Institute of British Architects sent last January to the Minister of Health a memorial expressing the readiness of the architectural profession to give assistance in the matter of slum clearance schemes, and pointing out that many of the local authority staffs have neither the time nor the experience to deal adequately with these large problems. Most people will admit the wisdom of employing a properly qualified professional man for any service, be it medical, legal or architectural, and the suggestion that public money should only be spent under competent professional advice appears to be sound reasoning. A great deal of time is given gratuitously by architects in serving on panels to assist in the improvement of designs submitted to local authorities, and through a very complete system of professional education the advice and service of competent men is now obtainable in all parts of the country.

\section{Recent Acquisitions at the British Museum (Natural History)}

OF all the regions of the world, the Pacific coast of South America is, perhaps, the most poorly represented in the Museum collection of fishes, and a representative series of the marine fishes of Chile has long been required. Through the kindness of Mr. V. Cavendish-Bentinck, of the British Embassy at Santiago, arrangements have been made with the Chilean fisheries authorities to supply the Department of Zoology with well-preserved specimens of the more important fishes. The first consignment of what promises to be a collection of considerable importance has now been received, and another consisting of specimens collected in the Juan Fernandez Islands is expected within a few weeks. Among the specimens acquired by exchange for the Zoological Department are examples of the Hawaiian land snail Achatinella. The species and races of these snails, which are often restricted to single ridges and ravines (in some cases even to single trees), are classical examples of the effects of isolation in speciesformation. The Department of Mineralogy has acquired by purchase a remarkable set of 98 meteoric stones which fell in 1869 as a shower at Tenham station, Kyabra County, South-West Queensland, and are as yet undescribed. Another purchase is a fine doubly-terminated crystal of ruby and a faceted colourless chrysoberyl $(7 \cdot 15$ carats) from the ruby 